\title{
Marked annual coral bleaching resilience of an inshore patch reef in the Florida Keys: A nugget of hope, aberrance, or last man standing?
}

\author{
Brooke E. Gintert ${ }^{1} \cdot$ Derek P. Manzello $^{2}$ (D) Ian C. Enochs ${ }^{2,3}$ - Graham Kolodziej ${ }^{2,3}$ • \\ Renée Carlton $^{4} \cdot$ Arthur C. R. Gleason $^{5} \cdot$ Nuno Gracias $^{6}$
}

Received: 30 June 2017/ Accepted: 22 March 2018/Published online: 27 March 2018

(C) The Author(s) 2018

\begin{abstract}
Annual coral bleaching events, which are predicted to occur as early as the next decade in the Florida Keys, are expected to cause catastrophic coral mortality. Despite this, there is little field data on how Caribbean coral communities respond to annual thermal stress events. At Cheeca Rocks, an inshore patch reef near Islamorada, FL, the condition of 4234 coral colonies was followed over $2 \mathrm{yr}$ of subsequent bleaching in 2014 and 2015, the two hottest summers on record for the Florida Keys. In 2014, this site experienced 7.7 degree heating weeks (DHW) and as a result $38.0 \%$ of corals bleached and an additional $36.6 \%$ were pale or partially bleached. In situ temperatures in summer of 2015 were even warmer, with the site
\end{abstract}

Topic Editor Dr. Simon Davy

Brooke E. Gintert and Derek P. Manzello have contributed equally to this work.

Derek P. Manzello

Derek.Manzello@noaa.gov

1 Department of Marine Geosciences, Rosenstiel School of Marine and Atmospheric Science, University of Miami, 4600 Rickenbacker Cswy., Miami, FL 33149, USA

2 Atlantic Oceanographic and Meteorological Laboratories (AOML), NOAA, 4301 Rickenbacker Cswy., Miami, FL 33149, USA

3 Cooperative Institute for Marine and Atmospheric Studies, Rosenstiel School of Marine and Atmospheric Science, University of Miami, 4600 Rickenbacker Cswy., Miami, FL 33149, USA

4 Khaled bin Sultan Living Oceans Foundation, Landover, MD, USA

5 Department of Physics, University of Miami, 1320 Campo Sano Ave., Coral Gables, FL 33146, USA

6 Vicorob Institute, University of Girona, Girona, Spain experiencing 9.5 DHW. Despite the increased thermal stress in 2015, only $12.1 \%$ of corals were bleached in 2015, which was 3.1 times less than 2014. Partial mortality dropped from $17.6 \%$ of surveyed corals to $4.3 \%$ between 2014 and 2015, and total colony mortality declined from 3.4 to $1.9 \%$ between years. Total colony mortality was low over both years of coral bleaching with $94.7 \%$ of colonies surviving from 2014 to 2016. The reduction in bleaching severity and coral mortality associated with a second stronger thermal anomaly provides evidence that the response of Caribbean coral communities to annual bleaching is not strictly temperature dose dependent and that acclimatization responses may be possible even with short recovery periods. Whether the results from Cheeca Rocks represent an aberration or a true resilience potential is the subject of ongoing research.

Keywords Cheeca Rocks - Sea temperature - Degree heating weeks - Caribbean coral community $\cdot$ Landscape mosaic $\cdot$ Acclimatization

\section{Introduction}

Annual coral bleaching is the greatest future threat to global coral reef health. Mass coral bleaching, the breakdown of the symbiosis between coral hosts and their algal symbionts, occurs when ocean temperatures exceed their long-term mean summer maximum by $1-2{ }^{\circ} \mathrm{C}$ for more than a month (Hoegh-Guldberg 1999). If elevated temperatures are sustained, coral mortality can occur. Coral bleaching events have become more common and more severe as ocean temperatures have increased due to global climate change and are predicted to intensify over time (Glynn 1993; Hoegh-Guldberg 1999; Hoegh-Guldberg 
et al. 2007; Baker et al. 2008). Annual bleaching is generally predicted to occur by 2050 for all reefs globally and could occur as early as 2020 for the Florida Keys (Manzello 2015).

Despite these concerns, coral bleaching events can have a range of potential outcomes. In the worst case, severe bleaching can lead to near $100 \%$ coral mortality with a loss of reef structural complexity and ecosystem function, as seen in the Galápagos Islands as a result of warming associated with the 1982-83 El Nino-Southern Oscillation (ENSO) (Glynn 1990). On the other end of the spectrum, corals can experience mild or 'seasonal' bleaching on an annual basis with little to no mortality (Fitt et al. 2000; Baker et al. 2008). The response is generally dose dependent, such that the greater the magnitude and duration of the positive deviation from average summertime temperatures, the greater the bleaching prevalence, severity, and mortality. There are negative ramifications to thermal stress and bleaching, even when corals survive the direct impacts. Thermally stressed and bleached corals are more disease susceptible, which can cause coral mortality for years beyond the time period of the thermal anomaly (Miller et al. 2009; Precht et al. 2016). Also, coral growth and reproductive output can be suppressed for years after bleaching (Baird and Marshall 2002; Cantin and Lough 2014; Levitan et al. 2014).

Despite a growing consensus that coral reefs will likely experience annual bleaching conditions across most reefs before the century is out, very little is known about how coral communities will respond under annual bleaching scenarios. Recent experimental work has begun to address the impacts of annual bleaching (Grottoli et al. 2014; Schoepf et al. 2015). Interestingly, the response of a given coral species to a single bleaching event was not a good predictor of back-to-back bleaching. Published field observations of annual bleaching are limited thus far to the Arabian Gulf (Riegl and Purkis 2015).

In 2014 and 2015, reefs of the Florida Keys experienced successive years of thermal bleaching as part of the 2014-2016 global bleaching event (NOAA Coral Reef Watch 2015). Corals in southeast Florida and the Florida Keys began experiencing coral bleaching in late August 2014 that was followed by a second year of bleaching in 2015 (NOAA Coral Reef Watch 2014, 2015). At Cheeca Rocks, Florida Keys, a long-term monitoring station was established in 2012 as part of NOAA's National Coral Reef Monitoring Program (NOAA Coral Program 2014). Since 2012, yearly coral reef image mosaics were acquired over six permanent reef sites to document detailed coral community information for over 4000 coral colonies through time. Here, we use these mosaics to document the impact of and recovery from the 2014 and 2015 bleaching events on the coral community at Cheeca Rocks under annual bleaching conditions.

\section{Methods}

\section{Mosaic surveys}

Beginning in July 2012, six permanent 10 by $10 \mathrm{~m}$ plots have been surveyed annually using image mosaics at Cheeca Rocks (24.8977 N, $80.6182 \mathrm{~W}$ ), which is a shallow (depth range $=2-6 \mathrm{~m}$ ) inshore patch reef in the Florida Keys, offshore of Islamorada (Fig. 1). Each mosaic plot was delineated using four permanent markers, one tag in each corner of the $10 \mathrm{~m} \times 10 \mathrm{~m}$ plot. A GPS coordinate was taken above each tag for geo-referencing and relocation purposes. A mosaic survey was then performed over the area delineated by the four corner markers. Plots were relocated in subsequent surveys by relocating the corner tags using printed mosaic maps to reduce searching time. Coral colonies were followed through time based on their geographic location within the mosaic image. Individual tagging of coral colonies was not needed using the mosaic survey method.

A mosaic image is a spatially explicit composite of hundreds to thousands of down-looking images acquired over the site. Dual Nikon D7000 cameras, one was set to a wide angle $(24 \mathrm{~mm})$ and one was set to a smaller field of view $(56 \mathrm{~mm})$, were used to capture images from approximately $2 \mathrm{~m}$ above the reef substrate. The pixel footprint of the wide-angle images is approximately $0.4 \mathrm{~mm}$. Divers swam the camera system in a dual lawn-mower pattern to ensure high overlap of site images. Images from the 24-mm camera were matched and blended into a spatially explicit composite as described in Lirman et al. (2007). The result of the mosaic process is a high-resolution photographic archive of all benthic organisms within the area of interest that can be used to assess coral community health at the time of the mosaic survey. Following the creation of the landscape mosaic, images from the 56- $\mathrm{mm}$ camera are matched to the frames of the landscape mosaic to create a multilayer mosaic with links to high-resolution still images as detailed in Gintert et al. (2009). The integrated mosaic and high-resolution images are used to improve coral species identification and health assessments as the pixel footprint of the 56-mm images is approximately $0.18 \mathrm{~mm}$.

During the summer of 2014, pale and partially bleached corals were documented during annual monitoring at Cheeca Rocks on August 11-12, 2014. Sea temperatures surpassed temperatures coincident with past Florida Keyswide bleaching events at the Molasses Reef Coastal Marine Automated Network (C-MAN) station on August 14, 2014 (Manzello et al. 2007a), and severe bleaching was first 


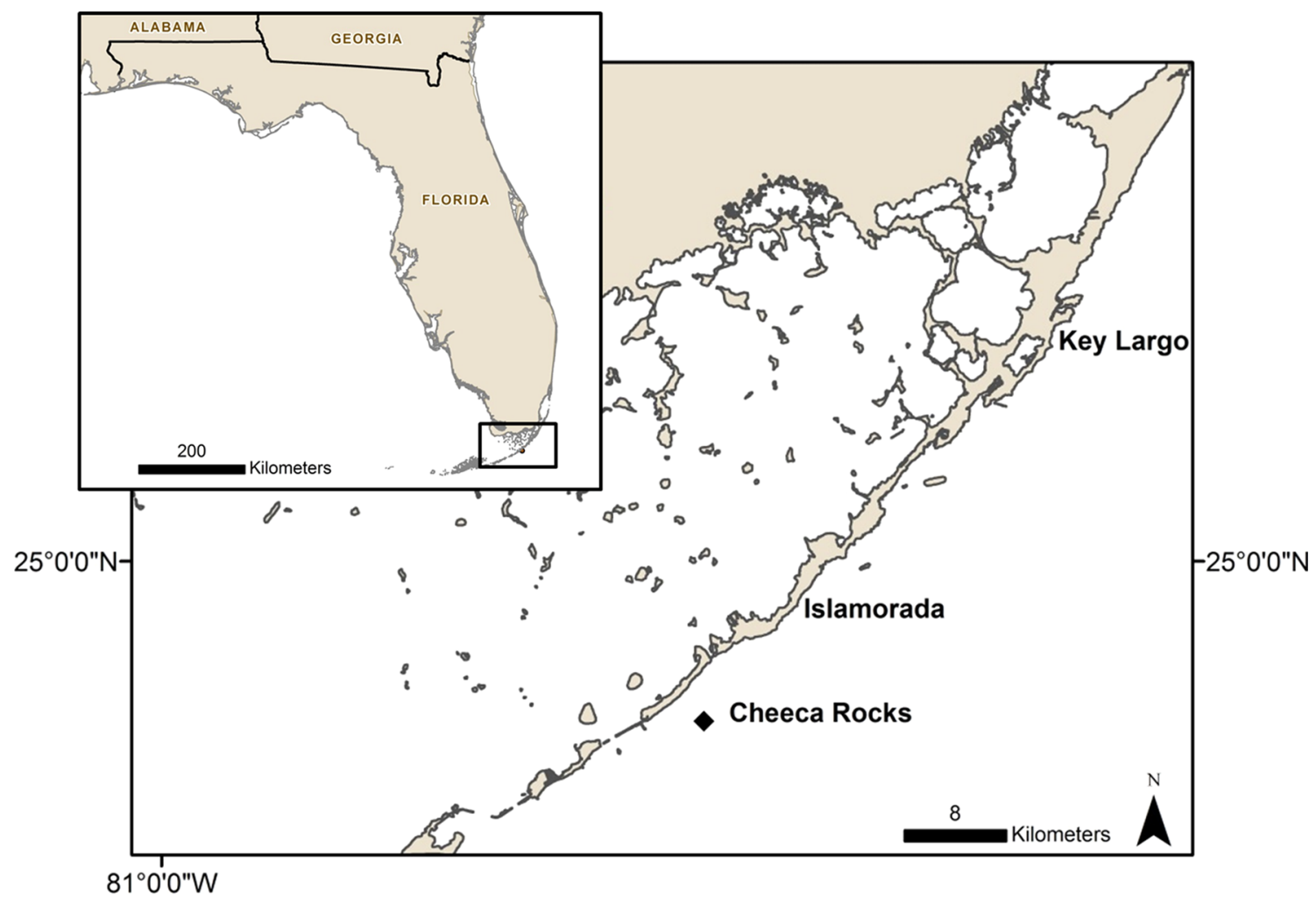

Fig. 1 Map of the Florida Keys and Cheeca Rocks

observed in Florida in late August. As a result, additional bleaching-related mosaic surveys were performed on September 16-17, 2014, and 6 months later on March $15-17,2015$, to document recovery. Surveys were conducted during the second bleaching event on October 9, 2015. The follow-up mosaic surveys were performed on July 11-12, 2016. An example of the mosaics collected at Cheeca Rocks, Florida, during the 2014 and 2015 bleaching events is shown in Fig. 2.

\section{Mosaic analysis}

Initial mosaic images of the six reef plots from 2012 were geo-referenced using real-world surface coordinates of permanent site markers. Repeat mosaics were geo-referenced to the initial mosaic image using permanent reef features, such as large distinctive corals, that could be identified by their location within the mosaic plot in multiple mosaic images. A minimum of 10 of these common points of interest were used for geo-referencing newly acquired mosaic images to previous mosaic surveys.

Following geo-referencing, the 2D boundaries of all coral colonies within the area of interest on each mosaic image were manually traced to create a colony-specific polygon in ArcGIS 10.1. For adjacent coral colonies of the same species, an individual coral colony was identified when there was no connection of tissue between two colonies. Coral colonies were identified to species and assessed for evidence of coral bleaching, disease, partial and total mortality in each mosaic survey. Polygons of corals that changed between years (mortality or growth) were redrawn to reflect the areal extent of living coral tissue at each survey time period. The severity of coral bleaching was assessed visually from zoomed-in images associated with the landscape mosaic. Coral colonies were assigned to four categories based on the visual appearance of the coral tissues. Corals that had no visual discoloration or bleaching of tissues were characterized as not bleached. Corals that had discoloration of the coral tissue, but did not have any patches of bleached/white tissue were categorized as pale. Coral color from the mosaics collected in 2012 and 2013 was used as a reference to differentiate non-bleached from pale tissues. Corals that had patches of fully bleached/ white tissue that covered part, but not all of the coral colony, were categorized as partially bleached, and any coral in which all visible tissue was fully bleached was categorized as bleached. Bleaching categories and visual guidelines for distinguishing between bleaching categories followed the Florida Reef Resilience Program guidelines (FRRP 2011), and the same classification scheme was applied to all survey years. The same two individuals 

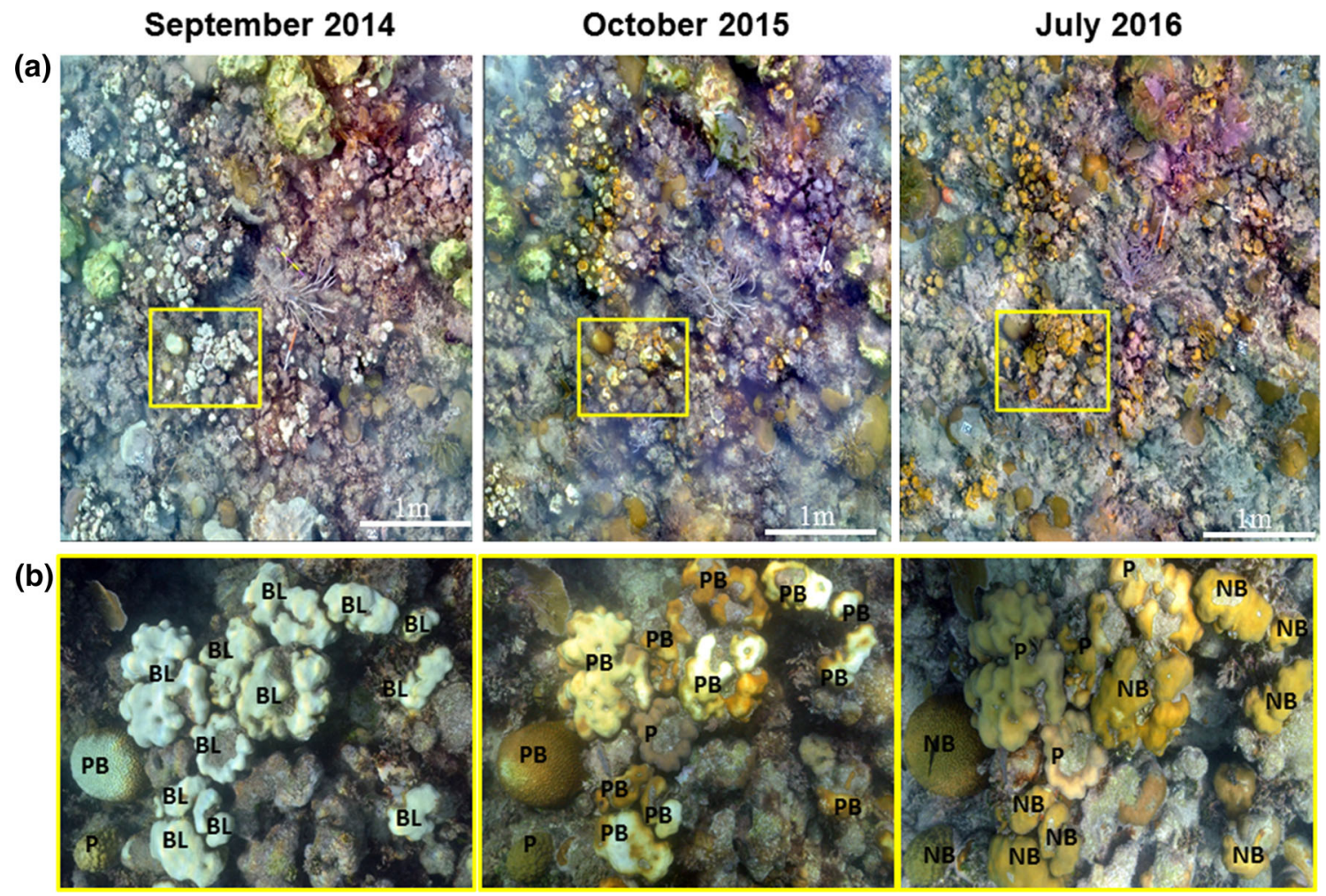

Fig. 2 An example mosaic (a) and zoomed-in images (b) of the benthic coral community at one of the six Cheeca Rocks permanent monitoring sites in September 2014 (bleaching), October 2015 (bleaching), and July 2016 (recovered)

conducted all the visual scoring of the mosaic images and worked together to ensure consistency.

A total of 4234 coral colonies were recorded, identified, and digitized across the six sites in 2014 and were followed

Table 1 Number of colonies assessed per year for bleaching and mortality

\begin{tabular}{lrrr}
\hline Species & 2014 & 2015 & 2016 \\
\hline Colpophyllia natans & 117 & 112 & 112 \\
Pseudodiploria clivosa & 6 & 6 & 6 \\
Diploria labyrinthiformis & 41 & 40 & 40 \\
Dichocoenia stokesi & 35 & 35 & 35 \\
Pseudodiploria strigosa & 24 & 23 & 22 \\
Orbicella annularis & 1148 & 1125 & 1121 \\
Montastraea cavernosa & 80 & 77 & 77 \\
Orbicella faveolata & 552 & 549 & 548 \\
Orbicella franksi & 8 & 8 & 8 \\
Millepora alcicornis & 28 & 23 & 23 \\
Porites astreoides & 789 & 746 & 699 \\
Porites porites & 333 & 308 & 282 \\
Stephanocoenia intersepta & 54 & 54 & 53 \\
Siderastrea radians & 126 & 102 & 100 \\
Siderastrea siderea & 893 & 878 & 876 \\
\hline
\end{tabular}

through time in successive mosaic surveys (Table 1). The effects of bleaching in 2014 were evaluated by combining the estimates of partial and total colony mortality assessed from the March 2015 and October 2015 mosaic surveys. Effects of the 2015 bleaching event were assessed from analysis of mortality documented in the July 2016 mosaic survey. Qualitative observations on August 23, September 29, and December 14, 2016, confirmed that there was no appreciable bleaching or disease in 2016.

\section{Temperature record}

Temperature was measured every $3 \mathrm{~h}$ at the Cheeca Rocks Moored Autonomous $\mathrm{pCO}_{2}$ buoy $\left(\mathrm{MAP}-\mathrm{CO}_{2}\right.$, depth $=1$ $\mathrm{m})$, from January 1, 2013, to December 31, 2016, using a conductivity-temperature sensor (Model SBE-16 plus v. 2.2, Seabird Electronics). Temperature data were also analyzed for the nearby Molasses Reef C-MAN station $(25.012 \mathrm{~N}, 80.376 \mathrm{~W})$. The Molasses Reef C-MAN data began in 1988 and extended through the end of 2015. A redundant temperature sensor (Seabird SBE 56) was attached to the C-MAN station in December 2013 and provided data for 2016 when the C-MAN data stream was non-continuous.

There were two small gaps in the Cheeca Rocks temperature record from August 29 to September 3, 2015 (6 d 
gap), and May 5-12, 2016 (8 d). The 2016 space was filled in with temperature data from a temperature probe (Seabird SBE 56) that was affixed to the reef bottom (3 m) approximately $250 \mathrm{~m}$ east of the buoy. The missing data in 2015 occurred because the buoy was pulled from the reef due to Tropical Storm Erika. This gap is more problematic given the decline in sea temperatures that occur with the passage of tropical storms (Manzello et al. 2007b). To account for this, we applied the same day-by-day decline in temperatures relative to August 28 measured at Molasses Reef coincident with the storm to the Cheeca Rocks daily average temperature on August 28. The maximum decline observed during the storm was $0.4^{\circ} \mathrm{C}$.

The maximum monthly mean (MMM) temperature of the Molasses Reef climatology from 1988 to 2005 for Molasses Reef is $29.9^{\circ} \mathrm{C}$ (Manzello et al. 2007a). The calculation of degree heating weeks (DHW) is based on deviations of sea temperature $\geq 1{ }^{\circ} \mathrm{C}$ above the MMM (Liu et al. 2006). However, when DHWs are calculated based on the MMM value of $29.9{ }^{\circ} \mathrm{C}+1{ }^{\circ} \mathrm{C}$, the bleaching threshold of $4 \mathrm{DHW}$ is a poor predictor of historical bleaching. Instead, mass coral bleaching in the Florida Keys has been correlated with monthly temperatures $\geq 30.4{ }^{\circ} \mathrm{C}$ at Molasses Reef (Manzello et al. 2007a). A $30.9{ }^{\circ} \mathrm{C}$ bleaching threshold may be erroneously high due to the fact that the Molasses Reef temperature record did not begin until 1988 and there is evidence that significant warming had already occurred in the Florida Keys by this time (Kuffner et al. 2015; Manzello 2015). Consequently, we chose to use the observed bleaching threshold of $30.4{ }^{\circ} \mathrm{C}$, rather than the calculated theoretic value. We made the assumption that the $\mathrm{MMM}$ is $29.4{ }^{\circ} \mathrm{C}$ for Molasses Reef, leading to DHW values for Molasses Reef that correspond to past bleaching years when $\mathrm{DHW}>4$ (Fig. 3a).

Given that we only have $4 \mathrm{yr}$ of temperature data for Cheeca Rocks, we cannot directly estimate a climatology or MMM to calculate DHW. We noted that the maximum running 30-d mean temperatures at Cheeca Rocks were $0.9{ }^{\circ} \mathrm{C}$ greater than the Molasses Reef value for each year that data overlapped (2013-2015). To estimate DHW for Cheeca Rocks, we thus added $0.9{ }^{\circ} \mathrm{C}$ to the Molasses Reef estimated MMM to get $30.3{ }^{\circ} \mathrm{C}$, yielding a bleaching threshold of $31.3{ }^{\circ} \mathrm{C}$ for Cheeca Rocks.

\section{Statistics}

The study sampled the same corals repeatedly, and no new corals were added to the sampled community between surveys. To compare bleaching and mortality prevalence of the entire coral community for the two bleaching events, multivariate permutational analysis of dissimilarity was conducted on the 15 most abundant corals. Species by transect matrices were constructed for counts of colonies for each visual bleaching score (not bleached, pale, partially bleached, bleached) and mortality. All data were square-root-transformed to minimize the influence of disproportionally prevalent species. Analyses were run using the adonis routine and $\mathrm{R}$ Studio (Team $\mathrm{R}$ 2015). Years (2014 vs. 2015 for bleaching; 2015 vs. 2016 for mortality) and sites $(n=6)$ were included as factors to test for significant differences in the two bleaching events, as well as differences between sites.

For the remaining statistical tests, we only assessed those eight species that were found at all six sites. To compare coral cover from 2014 through 2016, a Friedman test was used followed by Tukey post hoc tests. To ascertain species-specific trends, we used paired $t$ tests to assess differences in bleaching and mortality as these data conformed to the assumptions of a parametric test. Univariate analyses were performed with SigmaPlot 12.

\section{Results}

\section{Temperature}

The hottest summer on record based on DHW for the 29-yr Molasses Reef time series was 2015, followed by 2014 (Table 2, Fig. 3). Temperatures at Cheeca Rocks generally track the trends observed at Molasses Reef, suggesting that 2014 and 2015 were likely similarly extreme events at Cheeca Rocks (Fig. 3b). The DHW at both sites were nearly identical in 2014 (7.7 DHW at Cheeca Rocks and 7.5 DHW at Molasses Reef), while Molasses Reef had 10.9 DHW in 2015 versus 9.5 at Cheeca Rocks. Cheeca Rocks was warmer than Molasses in 2016 and reached 5.7 DHW.

\section{Prevalence of bleaching and mortality}

During the summer of $2014,74.6 \%$ of all corals surveyed exhibited some form of thermal stress (pale, partially bleached, or bleached) (Fig. 4a). Orbicella annularis had the highest bleaching prevalence in 2014 (74.1\%), followed by Porites porites (63.4\%), Colpophyllia natans (57.4\%), and Diploria labyrinthiformis (48.3\%) (Table 3). Bleaching prevalence was significantly different between 2014 and 2015 (multivariate permutational analysis of dissimilarity, $p<0.01)$. The percentage of colonies bleached in 2015 (mean \pm SEM $=12.1 \pm 4.15 \%$ ) was 3.1 times less than $2014(38.0 \pm 8.38 \%)$. The prevalence of paling was also different between years $(p<0.05)$, but followed an opposite pattern to bleaching. The prevalence of pale colonies in $2015(49.2 \pm 5.28 \%)$ was 3.8 times greater than in $2014(12.7 \pm 3.23 \%)$. 

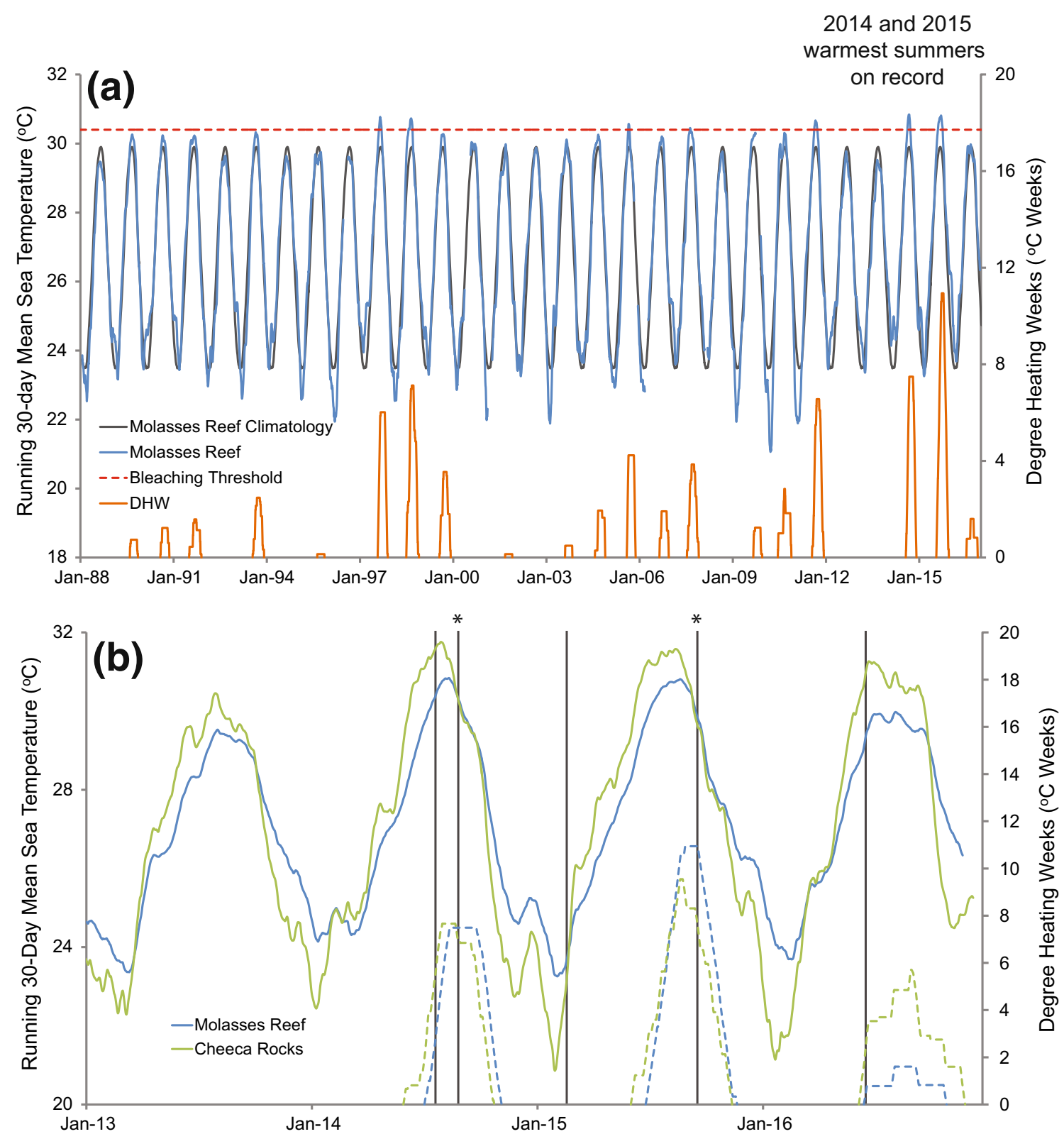

Fig. 3 a Time series of running 30-d mean seawater temperature from Molasses Reef plotted against climatology and degree heating weeks (DHW) since 1988, and b running 30-d mean temperatures and
DHW (dashed lines) for Cheeca Rocks and Molasses Reef from 2013 to 2016. Timing of surveys is indicated by gray bars. Asterisks indicate bleaching observed
Table 2 Degree heating weeks for Cheeca Rocks and Molasses Reef from 2013 to 2016. n/a, not applicable because this temperature data unavailable

\begin{tabular}{llll}
\hline Year & Cheeca Rocks & Molasses Reef, C-MAN & Molasses Reef, SBE-56 \\
\hline 2013 & 0 & 0 & n/a \\
2014 & 7.7 & 7.5 & 7.9 \\
2015 & 9.5 & 10.9 & 11.7 \\
2016 & 5.7 & n/a & 1.6 \\
\hline
\end{tabular}

Like bleaching, mortality was also less severe in 2015 than 2014. Total colony mortality was low following both the 2014 (3.4\% of all colonies) and 2015 (1.9\%) bleaching events (Table 4); $94.7 \%$ of colonies survived and recovered in 2016. Partial mortality also declined from 2014 to 2015 with the percentage of corals that experienced partial mortality dropping significantly from $17.6 \%$ in 2014 to $4.2 \%$ in 2015 ( $p<0.001$ ) (Fig. 4b). In 2015, Orbicella 

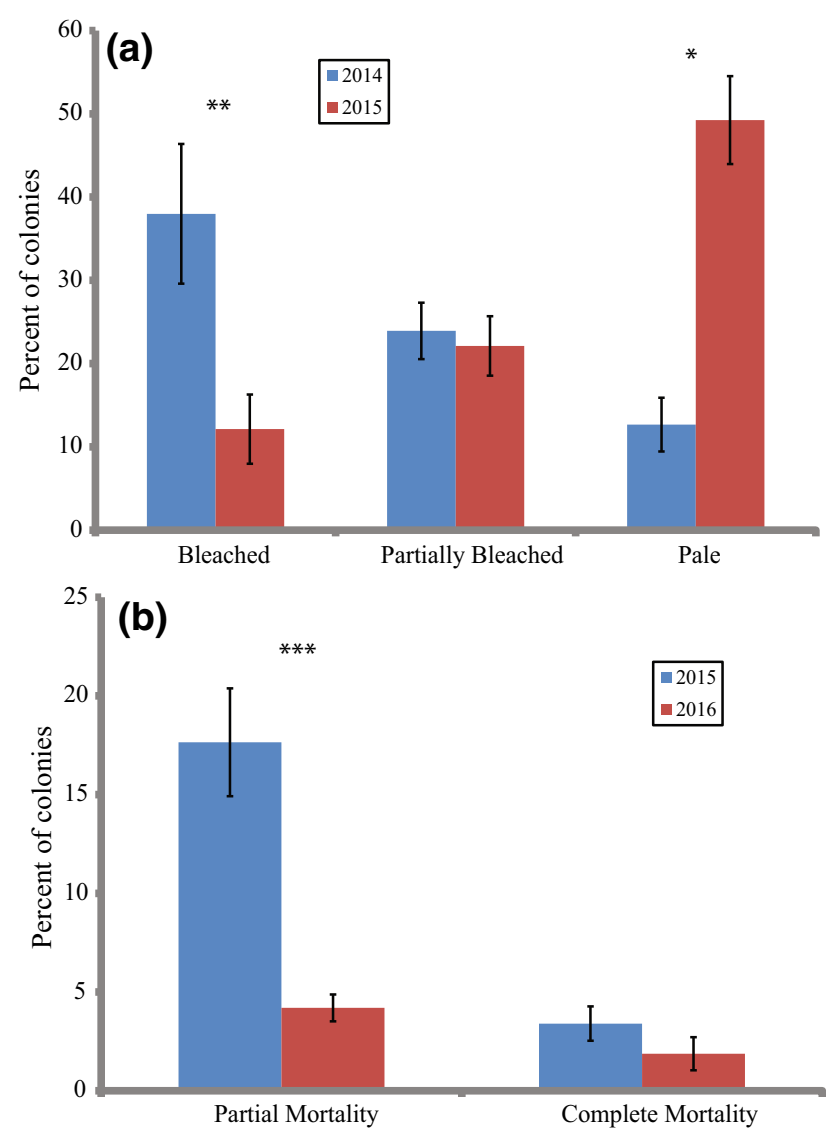

Fig. 4 a Percent of all coral colonies that were bleached, partially bleached, or pale in 2014 and 2015. b Percent of colonies that exhibited partial and complete mortality in 2015 and 2016. $* p<0.05$; $* * p<0.01 ; * * * p<0.001$ faveolata had the highest rates of partial mortality, with $43.9 \%$ of colonies exhibiting some partial mortality, but only $0.9 \%$ of colonies died (Table 4 ). Over both years, this species had the lowest rates of complete mortality. On the other hand, the three species that had the highest rates of complete mortality ( $P$. porites, $C$. natans, and Porites astreoides) also had high rates of partial mortality.

Seven of the eight species found at all sites had significantly lower bleaching prevalence in 2015 (Fig. 5b, Table 3). Only Siderastrea siderea had a slight increase in bleaching in 2015 with total bleaching increasing from 1.0 to $1.6 \%$ of all colonies from 2014 to 2015 . In general, partial bleaching declined slightly (Fig. 3), but this was only significant for $S$. siderea and $P$. astreoides. Partial bleaching increased for $O$. annularis (Fig. 5b); this was the only significant increase in bleaching or partial bleaching. Partial and complete mortality declined for all of the common species with only one exception (Fig. 6); more colonies of $P$. astreoides died after the 2015 bleaching event. All eight species had higher rates of paling in 2015, and this was significant for 7 of the 8 species (Fig. 5c).

\section{Fate tracking of coral colonies}

Not only were declines in bleaching severity noted in the prevalence data, but also fate tracking of the colonies that bleached in 2014 further illustrated that bleaching was less severe in 2015 (Fig. 7). Of the coral colonies that were completely bleached in 2014 , less than one-third $(31.9 \%)$ were completely bleached the following year (Fig. 7). The same trend was documented for corals that were partially

Table 3 Percent of coral colonies bleached, partially bleached, and pale during 2014 and 2015 bleaching event

\begin{tabular}{|c|c|c|c|c|c|c|c|c|c|c|c|c|}
\hline \multirow[t]{3}{*}{ Species } & \multicolumn{4}{|c|}{ Percent bleached } & \multicolumn{4}{|c|}{ Percent partially bleached } & \multicolumn{4}{|c|}{ Percent pale } \\
\hline & \multicolumn{2}{|l|}{2014} & \multicolumn{2}{|l|}{2015} & \multicolumn{2}{|l|}{2014} & \multicolumn{2}{|l|}{2015} & \multicolumn{2}{|l|}{2014} & \multicolumn{2}{|l|}{2015} \\
\hline & Mean & SEM & Mean & SEM & Mean & SEM & Mean & SEM & Mean & SEM & Mean & SEM \\
\hline Orbicella faveolata & 36.1 & 7.69 & 5.7 & 2.55 & 55.1 & 6.82 & 37.8 & 4.26 & 5.4 & 2.33 & 40.1 & 5.38 \\
\hline Siderastrea siderea & 1.0 & 0.41 & 1.6 & 1.59 & 13.1 & 2.36 & 1.9 & 1.65 & 22.3 & 3.94 & 62.1 & 4.16 \\
\hline Orbicella annularis & 74.1 & 11.30 & 30.1 & 8.16 & 17.2 & 5.23 & 48.3 & 5.81 & 8.0 & 6.44 & 20.9 & 5.84 \\
\hline Porites astreoides & 6.6 & 1.53 & 1.2 & 0.92 & 30.5 & 2.79 & 3.9 & 1.90 & 19.1 & 4.63 & 80.0 & 3.32 \\
\hline Colpophyllia natans & 57.4 & 3.69 & 3.1 & 1.50 & 35.1 & 1.87 & 15.8 & 8.81 & 4.2 & 2.33 & 67.7 & 12.33 \\
\hline Porites porites & 63.4 & 5.49 & 7.5 & 4.19 & 27.8 & 7.11 & 31.6 & 7.98 & 6.3 & 2.19 & 52.3 & 10.15 \\
\hline Montastraea cavernosa & 36.7 & 16.77 & 0.0 & 0.00 & 21.0 & 7.35 & 4.5 & 4.55 & 26.6 & 11.07 & 74.6 & 7.29 \\
\hline Diploria labyrinthiformis & 48.3 & 15.09 & 5.7 & 3.69 & 21.9 & 9.29 & 26.6 & 12.66 & 18.2 & 9.09 & 51.0 & 15.61 \\
\hline Total & 38.0 & 8.38 & 12.1 & 4.15 & 23.9 & 3.38 & 22.1 & 3.57 & 12.7 & 3.23 & 49.2 & 5.28 \\
\hline
\end{tabular}

Data for the 8 species found at each site are shown in order of relative abundance, as well as total data on the 15 most common species SEM standard error of the mean 
Table 4 Percent of colonies that showed partial and complete mortality in 2015 and 2016

\begin{tabular}{|c|c|c|c|c|c|c|c|c|}
\hline \multirow[t]{3}{*}{ Species } & \multicolumn{4}{|c|}{ Percent partial mortality } & \multicolumn{4}{|c|}{ Percent complete mortality } \\
\hline & \multicolumn{2}{|l|}{2015} & \multicolumn{2}{|l|}{2016} & \multicolumn{2}{|l|}{2015} & \multicolumn{2}{|l|}{2016} \\
\hline & Mean & SEM & Mean & SEM & Mean & SEM & Mean & SEM \\
\hline Orbicella faveolata & 43.9 & 5.85 & 9.9 & 5.39 & 0.9 & 0.76 & 0.2 & 0.17 \\
\hline Siderastrea siderea & 8.0 & 2.54 & 1.0 & 0.36 & 1.4 & 0.69 & 0.2 & 0.19 \\
\hline Orbicella annularis & 7.8 & 1.48 & 3.8 & 1.80 & 2.6 & 0.83 & 1.6 & 0.77 \\
\hline Porites astreoides & 21.3 & 3.50 & 12.0 & 4.43 & 3.5 & 1.28 & 4.7 & 1.32 \\
\hline Colpophyllia natans & 21.3 & 3.04 & 12.3 & 3.69 & 4.6 & 2.15 & 0.0 & 0.00 \\
\hline Porites porites & 19.1 & 6.94 & 9.3 & 3.01 & 8.0 & 2.40 & 7.0 & 2.65 \\
\hline Montastraea cavernosa & 20.1 & 6.85 & 0.0 & 0.00 & 1.9 & 1.26 & 0.0 & 0.00 \\
\hline Diploria labyrinthiformis & 11.4 & 7.38 & 0.0 & 0.00 & 3.3 & 3.33 & 0.0 & 0.00 \\
\hline Total & 17.6 & 2.73 & 4.2 & 0.68 & 3.4 & 0.87 & 1.9 & 0.84 \\
\hline
\end{tabular}

Data for the 8 species found at each site are shown, as well as pooled data on the 15 most common species bleached in 2014 . The majority of partially bleached corals from 2014 were either pale $(57.1 \%)$ or not bleached $(18.9 \%)$ during the thermal stress of 2015. For corals documented as pale in the summer of 2014 , the majority $(74.6 \%)$ were documented as pale the following year, with $17.9 \%$ showing no visible signs of thermal stress in 2015 (Fig. 7). Only those colonies that were not observed with visual signs of bleaching stress in 2014 had increased bleaching prevalence in 2015. In this case, $65.6 \%$ of corals that were not bleached in 2014 were pale in 2015 . Only $5.0 \%$ of non-bleached corals in 2014 were found to be either partially bleached or bleached in 2015 (Fig. 7).

The percentage of corals exhibiting partial mortality declined within each group from 2014 to 2015 (Fig. 8). Only $2.6 \%$ of the completely bleached corals in 2014 suffered complete mortality, and this declined to $1.2 \%$ in 2015 (Fig. 8). For corals that were partially bleached in 2014, 2.2\% died following the 2014 event compared with $1.3 \%$ in the year following the 2015 event. The percentage of corals documented as pale in 2014 and 2015 had similar levels of total colony mortality between years ( 2.3 and $2.9 \%$, respectively). Interestingly, those corals that did not bleach in 2014 had the highest complete colony mortality $(5.7 \%)$.

\section{Bleaching resistance and resilience}

Corals that had no visible signs of bleaching (paling, partial bleaching, or bleached) during both bleaching surveys were labeled as bleaching resistant. Of the 4100 corals that were assessed in both years, only $302(7.4 \%)$ showed no signs of bleaching during both bleaching surveys. Four common species, Pseudodiploria clivosa, Pseudodiploria strigosa, $O$. annularis, and D. labyrinthiformis, had $0 \%$ bleaching resistance, meaning that all surveyed colonies of these species were documented with some level of bleaching stress over the 2-yr time period (Fig. 9). Orbicella franksi was the most resistant species to thermal bleaching with $37.5 \%$ of the surveyed colonies showing no signs of bleaching during either bleaching event. Only three other coral species, Dichocoenia stokesi (25.7\%), S. siderea (24.3\%), and Stephanocoenia intersepta (13.0\%), had more than $10 \%$ of their colonies that withstood the anomalously high temperatures of 2014 and 2015 without signs of bleaching (Fig. 9).

Bleaching resilience, defined here as the percentage of colonies within a species that showed visual signs of bleaching, including those that were partially bleached or bleached, during the elevated temperatures of 2014 and 2015 without suffering total colony mortality, was $>92 \%$ for all fifteen of the most common coral species. Eight of the 15 most common species had $0 \%$ complete mortality which resulted in $100 \%$ bleaching resilience (Fig. 9). An additional five species had between 95 and $100 \%$ species resilience over the time period (Fig. 9). Only two species, $P$. astreoides and $P$. porites, had more than $5 \%$ of colonies suffer complete mortality $(<95 \%$ bleaching resilience between 2014 and 2016).

\section{Coral cover}

Mean coral cover declined $3.7 \%$ from $29.2 \% \pm 2.97$ (mean $\pm \mathrm{SE}$ ) to $25.5 \% \pm 1.60$ over the six permanent plots between September 2014 and July 2016, which was significant (Friedman's test, $X^{2}=12, p<0.001$ ) (Table 5). This decline was significant for five of the eight most common species: $O$. faveolata, $S$. siderea, $P$. astreoides, $P$. porites, and Montastraea cavernosa. This was driven by significantly lower coral cover in 2016 relative to cover before bleaching in 2014 (Tukey post hoc tests, $p<0.05$ ). Only $M$. cavernosa saw a significant decline in coral cover after the first year of bleaching. Relative coral cover 

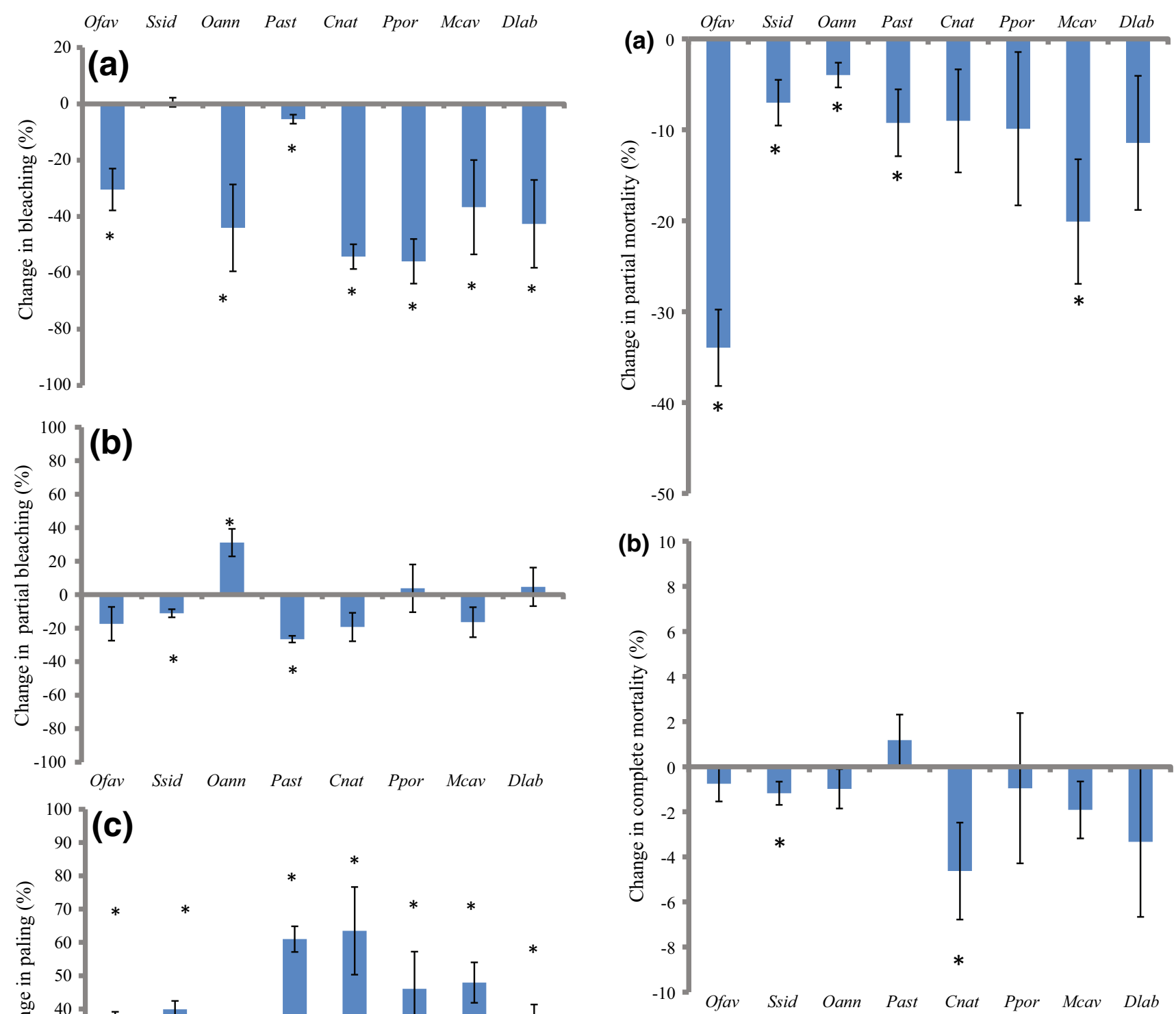

Fig. 6 Change in percentage of colonies that had undergone a partial mortality and b complete mortality as observed during the March 2015 and July 2016 surveys for those species found at all six sites. Asterisks indicate significant difference. Species abbreviations same as Fig. 5

\section{Discussion}

Fig. 5 Change in percentage of colonies that were a bleached, b partially bleached, or c pale during the September 2014 and October 2015 surveys for those species found at all six sites. Asterisk indicates significant difference. Species abbreviations: Ofav, Orbicella faveolata; Ssid, Siderastrea siderea; Oann, Orbicella annularis; Past, Porites astreoides; Cnat, Colpophyllia natans; Ppor, Porites porites; Mcav, Montastraea cavernosa; Dlab, Diploria labyrinthiformis

increased for S. siderea, O. annularis, C. natans, M. cavernosa, and $D$. labyrinthiformis following the bleaching events of 2014 and 2015 (Table 5), but the order of relative abundance did not change.

During the longest global bleaching event on record, we found possible evidence for community-wide acclimatization from annual coral bleaching at Cheeca Rocks in the Florida Keys. Bleaching severity and partial mortality were reduced for the vast majority of coral species following the 2015 event relative to 2014. Despite a 34\% increase in DHWs in the second year of bleaching at Cheeca Rocks in 2015, all but two of the 15 most common coral species had reductions in bleaching and total mortality between years, and all 15 had reduced partial mortality following the 2015 event when compared to 2014. The two species that had 
Bleached in $2014 \quad$ Partially Bleached Pale in $2014 \quad$ Not Bleached in 2014 in 2014
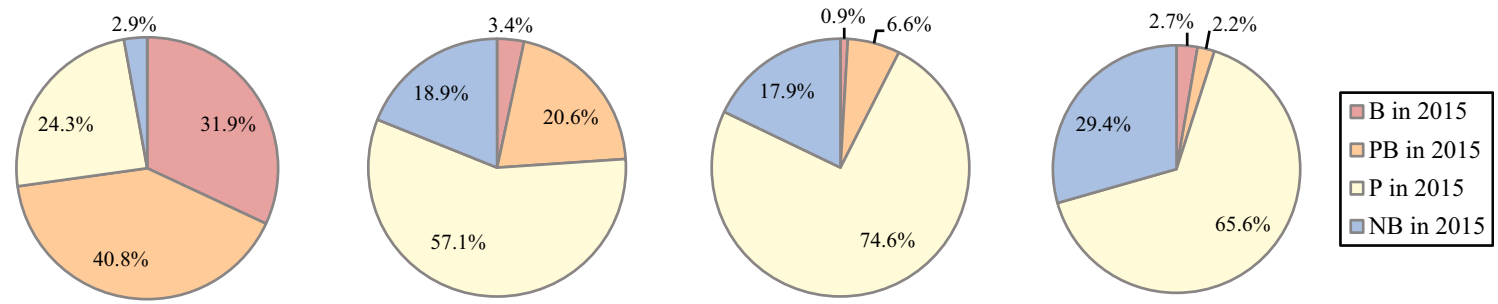

Fig. 7 Bleaching response of tracked colonies in 2015 as a function of their response in 2014

(a) Bleached in 2014

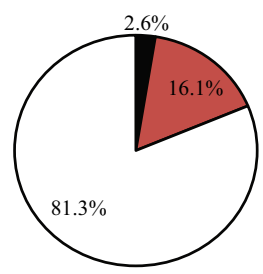

(b) Bleached in 2015

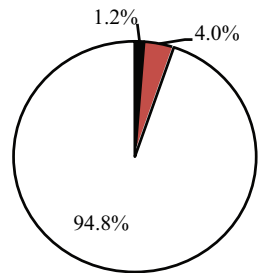

Partially Bleached in 2014

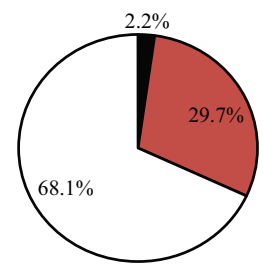

Partially Bleached in 2015

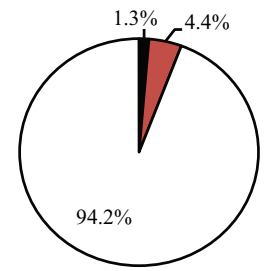

Pale in 2014

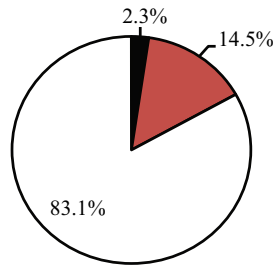

Pale in 2015

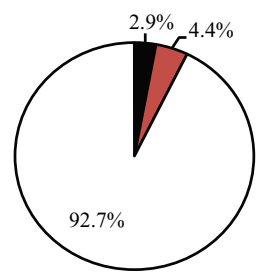

Not Bleached in 2014

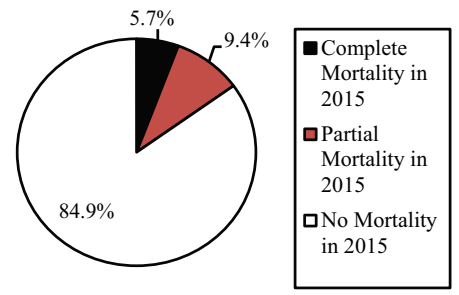

Not Bleached in 2015

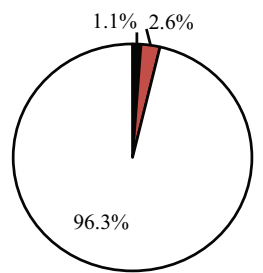

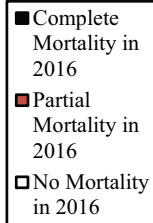

Fig. 8 Fate of bleached, partially bleached, pale, and unbleached corals in the year following the 2014 and 2015 coral bleaching events at Cheeca Rocks, Florida

increases in bleaching prevalence ( $S$. intersepta and Siderastrea radians) were not abundant; they were not observed at all sites and only made up $\leq 0.2 \%$ of the total coral cover. These species were also highly resistant to bleaching in both years as $<8 \%$ of all colonies bleached in either year. Only two species of the fifteen most common ( $P$. astreoides and $S$. intersepta) experienced a slight increase in total colony mortality in 2015; however, the uptick was $<2.0 \%$ for both these species when all other species saw reductions in total colony mortality from 2014 to 2015 .

Although the idea that corals can be less impacted by a second bleaching event may seem counterintuitive, this has been documented before in the eastern tropical Pacific, the Great Barrier Reef, French Polynesia, SE Asia, the Maldives, and Kenya (Glynn et al. 2001; Maynard et al. 2008; Thompson and van Woesik 2009; Guest et al. 2012;
Pratchett et al. 2013; McClanahan and Muthiga 2014; McClanahan 2017). Other studies have reported the more intuitive trend of compounded impacts from repeated thermal stress events (e.g., Neal et al. 2016). All of these studies, however, deal with bleaching events separated by multiple years and are not representative of an annual bleaching scenario. Annual bleaching and disease have been documented in consecutive years in the Arabian/ Persian Gulf in which the combined effects of disease and bleaching caused dramatic shifts in coral community composition over time due to the differential susceptibility of widespread coral species (Riegl and Purkis 2015). Riegl and Purkis (2015) documented 4 yr of mortality, but this was initially driven by disease in the first 2 yr. Bleaching prevalence in their study did not reach levels documented herein until year three. While disease and temperature stress are inarguably linked, the Arabian Sea example 


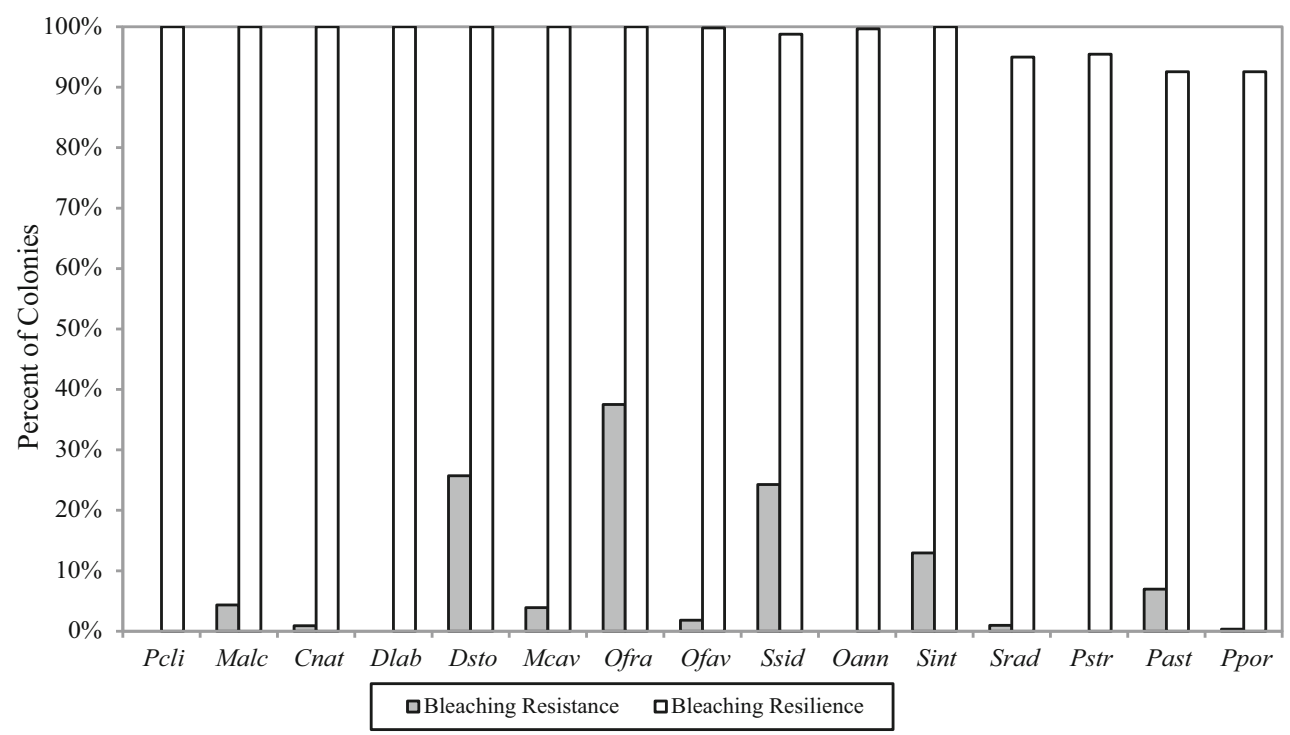

Fig. 9 Proportion of corals showing bleaching resistance and bleaching resilience during both the 2014 and 2015 thermally induced bleaching events. Bleaching resistance is defined as percentage of colonies that showed no signs of bleaching during either the 2014 and the 2015 mosaic sampling events. Bleaching resilience is defined as percentage of colonies that survived between September 2014 and July 2016. Species abbreviations: Pcli, Pseudodiploria clivosa; Malc,
Millepora alcicornis; Cnat, Colpophyllia natans; Dlab, Diploria labyrinthiformis; Dsto, Dichocoenia stokesi; Mcav, Montastraea cavernosa; Ofra, Orbicella franksi; Ofav, Orbicella faveolata; Ssid, Siderastrea siderea; Oann, Orbicella annularis; Sint, Stephanocoenia intersepta; Srad, Siderastrea radians; Pstr, Pseudodiploria strigosa; Past, Porites astreoides; Ppor, Porites porites

Table 5 Mean absolute and relative mean percent coral cover from 2014 to 2016

\begin{tabular}{|c|c|c|c|c|c|c|c|c|c|c|c|c|}
\hline \multirow[t]{2}{*}{ Species } & \multicolumn{3}{|l|}{2014} & \multicolumn{3}{|l|}{2015} & \multicolumn{3}{|l|}{2016} & \multicolumn{3}{|c|}{ Friedman's test } \\
\hline & $\begin{array}{l}\text { Mean } \\
\text { cover } \\
(\%)\end{array}$ & SEM & $\begin{array}{l}\text { Relative } \\
\text { cover }(\%)\end{array}$ & $\begin{array}{l}\text { Mean } \\
\text { cover } \\
(\%)\end{array}$ & SEM & $\begin{array}{l}\text { Relative } \\
\text { cover }(\%)\end{array}$ & $\begin{array}{l}\text { Mean } \\
\text { cover } \\
(\%)\end{array}$ & SEM & $\begin{array}{l}\text { Relative } \\
\text { cover }(\%)\end{array}$ & $X^{2}$ & $P$ & Tukey post hoc \\
\hline $\begin{array}{l}\text { Orbicella } \\
\text { faveolata }\end{array}$ & 14.7 & 4.61 & 50.4 & 13.7 & 4.27 & 50.1 & 12.1 & 3.54 & 47.4 & 12.0 & $* * *$ & $2014>2016$ \\
\hline $\begin{array}{l}\text { Siderastrea } \\
\text { siderea }\end{array}$ & 6.0 & 1.18 & 20.4 & 5.9 & 1.15 & 21.5 & 5.9 & 1.15 & 23.1 & 11.6 & $* * *$ & $2014>2016$ \\
\hline $\begin{array}{l}\text { Orbicella } \\
\text { annularis }\end{array}$ & 2.2 & 0.97 & 7.6 & 2.1 & 0.91 & 7.8 & 2.1 & 0.90 & 8.3 & ns & ns & ns \\
\hline $\begin{array}{l}\text { Porites } \\
\text { astreoides }\end{array}$ & 1.8 & 0.55 & 6.3 & 1.6 & 0.47 & 5.8 & 1.5 & 0.43 & 5.8 & 12.0 & $* * *$ & $2014>2016$ \\
\hline $\begin{array}{l}\text { Colpophyllia } \\
\text { natans }\end{array}$ & 1.4 & 0.29 & 4.8 & 1.4 & 0.28 & 5.0 & 1.3 & 0.27 & 5.2 & ns & ns & ns \\
\hline Porites porites & 0.9 & 0.33 & 3.2 & 0.8 & 0.32 & 3.1 & 0.8 & 0.31 & 3.1 & 11.6 & $* * *$ & $2014>2016$ \\
\hline $\begin{array}{c}\text { Montastraea } \\
\text { cavernosa }\end{array}$ & 0.8 & 0.40 & 2.6 & 0.7 & 0.40 & 2.7 & 0.7 & 0.40 & 2.9 & $5.2^{\mathrm{a}}$ & $*$ & $\begin{array}{l}2014>2015 \\
2014>2016\end{array}$ \\
\hline $\begin{array}{l}\text { Diploria } \\
\quad \text { labyrinthiformis }\end{array}$ & 0.4 & 0.22 & 1.3 & 0.4 & 0.22 & 1.3 & 0.4 & 0.22 & 1.4 & ns & ns & $\mathrm{ns}$ \\
\hline Total & 29.2 & 2.97 & & 27.4 & 2.67 & & 25.5 & 1.60 & & 12.0 & $* * *$ & $2014>2016$ \\
\hline
\end{tabular}

Data for the 8 species found at each site, as well as 15 most common species. Pre-bleaching data are 2014 and post-bleaching recovery data are 2016. SEM is standard error of the mean percent cover. Results of Friedman's test and Tukey post hoc comparison if applicable. Tukey post hoc column indicates years that were significantly different

$n s$ nonsignificant

$P$ values abbreviated as follows: $*<0.05 ; * *<0.01 ; * * *<0.001$

${ }^{a}$ Repeated measures ANOVA used because data met assumptions, thus represents $F$ value 
appears to be a disease event that was then exacerbated by the additive stressor of bleaching.

The community acclimatization and increased survival noted during repeat bleaching at Cheeca Rocks has not been observed for all species in experimental studies. Work simulating annual bleaching conditions in Caribbean corals found that species responses to back-to-back years of coral bleaching had varied results, and species responses to a single bleaching event were not predictive of results in the following year (Grottoli et al. 2014; Schoepf et al. 2015). In these experiments, $P$. astreoides, a so-called winner that was resilient to a single bleaching event, fared poorly in terms of its physiological response when bleaching occurred $2 \mathrm{yr}$ in a row. Conversely, $P$. divaricata, a bleaching 'loser,' was able to acclimatize and become a winner, displaying minimal physiological stress in year two.

The species-specific trends reported by Grottoli et al. (2014) did not clearly play out at Cheeca Rocks. P. astreoides experienced significantly less bleaching, partial bleaching, and partial mortality in the second year at Cheeca Rocks, FL. P. astreoides was, however, the only species that experienced an increase in total colony mortality during the second year of bleaching. $P$. divaricata, a species that showed marked acclimatization in a second year of simulated bleaching, is not found at Cheeca Rocks; however, the related species P. porites (Prada et al. 2014) experienced significantly less bleaching and had lower rates of partial and total mortality in 2015 when compared to the previous year. $P$. porites and $P$. astreoides had the lowest survival at Cheeca Rocks; 91.5 and $93.7 \%$ of colonies survived, respectively. Thus, relative to the other coral species, both poritids were losers, but still had high survival rates over two consecutive years of bleaching.

The annual bleaching response of $O$. faveolata under simulated conditions was more complex, as it was more impacted in the second year of bleaching than the first, but exhibited a quick recovery (Grottoli et al. 2014). In our study, $O$. faveolata exhibited less partial and complete colony bleaching during the second bleaching event (Fig. 5). Partial mortality declined from $45.6 \%$ in 2014 to $6.2 \%$ in 2015 . Less than $1 \%$ of the $O$. faveolata colonies died in 2014 or 2015 (Fig. 7). Overall, the majority of coral species at Cheeca Rocks followed the pattern displayed by $O$. faveolata, in which levels of bleaching and partial mortality declined from 2014 to 2015 , while total colony mortality was limited in both surveyed years. As a result, after $1 \mathrm{yr}$ of recovery from annual bleaching, there were no striking community-level divergence patterns observed among the dominant coral species at Cheeca Rocks. Although coral cover declined due to the multi-year bleaching event from 29.2 to $25.5 \%$ across the six surveyed plots, the relative dominance of the 15 studied species was the same after the bleaching recovery in 2016 than before bleaching began in 2014 (Table 3).

It is important to note that we are reporting colorimetric determinations of bleaching and this is known to have limitations because visual appearance does not always conform to physiological performance (Fitt et al. 2001; Manzello et al. 2009). For example, Grottoli et al. (2014) found that $O$. faveolata remained brown in color after the second year of heat stress, but actually showed greater physiological impairment than the first year when it turned white. Future broad-scale surveys should incorporate tissue sampling for measurement of zooxanthellae densities, whenever possible, to better quantify coral bleaching. Furthermore, the addition of standardized color charts would also increase the robustness of visual scoring (e.g., Siebeck et al. 2009). In spite of the limitations of visual assessments as a signal of coral stress, there is evidence of resilience at Cheeca Rocks, defined here as the ability of a coral colony to survive repeated bleaching. Eight of the fifteen most common corals at Cheeca Rocks had very high resilience and suffered no total colony mortality between 2014 and 2016, with an additional five species having $>95 \%$ bleaching resilience over the survey period (Fig. 9).

The recovery and resilience of corals to bleaching has been linked to host genotype, shifts in symbiont types, energy reserves, the ability of corals to supplement energy demands with heterotrophy, high flow rates, and turbidity (Edmunds 1994; Nakamura and van Woesik 2001; Baker et al. 2004; Grottoli et al. 2014; Connolly et al. 2012; Guest et al. 2016 and others). Resistance to bleaching can be promoted by high thermal variability, thermal history of a site, high dosages of photosynthetically active radiation prior to thermal stress, and high cloud cover during times of thermal stress (Mumby et al. 2001; Brown et al. 2002; Thompson and van Woesik 2009). It's possible the patterns observed in this study could be due to switching to more heat-tolerant zooxanthellae types, like Symbiodinium trenchii (D1a), in response to the 2014 bleaching (e.g., LaJeunesse et al. 2009). Further study is necessary to understand the role of symbiont type in the bleaching dynamics at this site.

It is currently unknown how much the physical environment of the study reef played in the acclimatization potential of these corals. Cheeca Rocks is an inshore patch reef with much higher living coral cover (29.2\% in 2014) than is found elsewhere in the Florida Keys and also the wider Caribbean (Gardner et al. 2003; Ruzicka et al. 2013). Patch reef communities in the Florida Keys exist in an environment that has greater fluctuations in temperature and increased sedimentation, turbidity, and nutrients relative to offshore reefs (Lirman and Fong 2007). These environmental characteristics are typically considered 
detrimental to reef development, and yet inshore patch reefs of the Florida Keys are healthier in terms of percent coral cover, growth rates, and levels of partial mortality relative to their offshore counterparts (Lirman and Fong, 2007). These inshore reef sites also experience highly variable seawater carbonate chemistry, with some of the highest seasonal aragonite saturation state values ever documented (Manzello et al. 2012). Coral extension and calcification of $O$. faveolata and $P$. astreoides are higher at Cheeca Rocks relative to reefs offshore and showed a marked resilience to previous coral bleaching events (Manzello et al. 2015a, b).

Oliver and Palumbi (2011) showed that conspecifics that originate in environments with larger annual temperature fluctuations have greater heat tolerance than corals that originate from less fluctuating environments regardless of symbiont type. The higher turbidity may also be a key characteristic of Cheeca Rocks as a turbid reef site in Singapore was shown to be highly resilient to bleaching (Guest et al. 2016). A similar pattern occurred in Palau, where coral bleaching and mortality were lower in sheltered bays that experience higher temperatures and lower irradiance due to high suspended particulate matter (van Woesik et al. 2012). Light data spanning the two bleaching events at Cheeca Rocks are unavailable; thus, we cannot rule out that reduced light in 2015 may have tempered the bleaching response despite warmer temperatures.

Finally, surveys in 2015 took place later in the year than they did in 2014 (Fig. 3b). It is possible that the lower bleaching prevalence in 2015 could be due in part to seasonally declining temperatures and dosages of light. In other words, we may have surveyed the coral community after some recovery had taken place, missing peak bleaching prevalence. DHWs peaked at Cheeca Rocks from September 14 to 18,2015 , at $9.5^{\circ}$-weeks. Our surveys took place on October 9 , which was indeed 3 weeks after this peak. However, DHWs on October 9, 2015, were still $8.1^{\circ}$-weeks, higher than the maximum value reached in 2014 of $7.7^{\circ}$-weeks. Thus, while some recovery may have taken place in the 3 weeks since peak DHWs, the DHW values during the 2015 surveys were still greater than the maximum values reached in 2014. The conclusions of this study were not solely drawn from the visual surveys of coral color, but were also based on the incidence of partial and total colony mortality, both of which declined in 2015 despite higher thermal stress. Even with the limitations associated with the colorimetric determination of bleaching and later sampling in 2015, the lower rates of mortality illustrate the reduced impact during the second year of bleaching.

The results here provide a degree of tempered optimism, or 'nugget of hope,' that annual coral bleaching may not result in complete mortality due to compounded stress events and small recovery periods. These data show that acclimatization of an entire coral community is possible under annual bleaching conditions, yet this was not enough to prevent coral bleaching and mortality entirely in the second year at Cheeca Rocks. In addition, it is currently unknown if the multiple years of bleaching studied at Cheeca Rocks have made the corals more susceptible to other stressors such as coral disease or additional thermal stress. Throughout south Florida, there is an ongoing coral disease event that began coincident with the thermal stress in 2014 that is having locally catastrophic consequences (e.g., Precht et al. 2016). As of the time that this manuscript was written, this disease event has yet to impact Cheeca Rocks.

The coral community at Cheeca Rocks is admittedly only one reef site that is a clear outlier to the wider trends in the Florida Keys and Caribbean. Overall, Florida Keys' reefs have deteriorated greatly since the late 1970s (Dustan and Halas 1987; Porter and Meier 1992). Coral cover on offshore reefs is on average $<5 \%$ and continues to decline (Ruzicka et al. 2013). The disparity between Cheeca Rocks, which maintained $25 \%$ coral cover after the two warmest summers on record, with the state of reefs in the wider Florida Keys is striking. This example could simply be an example of aberrance, or a site that has not yet been pushed past its particular resilience threshold. It is unclear if this site could continue to exhibit the same level of resilience and acclimatization under greater heat stress, such as DHWs in excess of 10. If not, it may just be a matter of time before this site experiences a level of heat stress that causes mass coral mortality. Even with the documented acclimatization, there was still a $3.7 \%$ decline in coral cover from 2014 to 2016 . If this reef loses $2 \%$ coral cover per year under an annual bleaching scenario, then all coral would be lost by attrition in roughly $13 \mathrm{yr}$ at the coverage levels in $2016(25.5 \%$ mean coral cover, Table 5). There would need to be an increase in bleaching resilience or resistance of this community to persist with bleaching every year for more than a decade.

The long-term resilience of inshore patch reef communities in comparison with offshore reefs of the Florida Keys suggests that these sites are important for understanding coral resilience potential and can be informative for reef management in an era of global change, especially if this site proves to be resistant to the region-wide disease event as well. Suboptimal environmental conditions appear to lend some degree of resistance and resilience to bleaching as has been shown in Singapore and Palau (van Woesik et al. 2012; Guest et al. 2016) and suggest that these reef sites likely deserve special attention. The next research step is to try and unravel the biological versus environmental factors that are leading to the resilience of the coral 
community at Cheeca Rocks and compare/contrast the key attributes with other sites around the globe.

Acknowledgements The authors thank NOAA's Coral Reef Conservation Program and Ocean Acidification Program for funding this work as part of the National Coral Reef Monitoring Program. We thank the Florida Keys National Marine Sanctuary for their support of this work (Permits \#FKNMS-2011-160 and FKNMS-2016-120). J. Delaney of FKNMS provided valuable assistance with permitting. The manuscript contents are solely the opinions of the authors and do not constitute a statement of policy, decision, or position on behalf of NOAA or the US Government.

\section{Compliance with ethical standards}

Conflict of interest All authors declare that there is no conflict of interest.

Open Access This article is distributed under the terms of the Creative Commons Attribution 4.0 International License (http://crea tivecommons.org/licenses/by/4.0/), which permits unrestricted use, distribution, and reproduction in any medium, provided you give appropriate credit to the original author(s) and the source, provide a link to the Creative Commons license, and indicate if changes were made.

\section{References}

Baker AC, Glynn PW, Riegl B (2008) Climate change and coral reef bleaching: an ecological assessment of long-term impacts, recovery trends and future outlook. Estuar Coast Shelf Sci 80:435-471

Baker AC, Starger CJ, McClanahan TR, Glynn PW (2004) Corals' adaptive response to climate change. Nature 430:741

Baird AH, Marshall PA (2002) Mortality, growth and reproduction in scleractinian corals following bleaching on the Great Barrier Reef. Mar Ecol Prog Ser 237:133-141

Brown BE, Dunne RP, Goodson MS, Douglas AE (2002) Experience shapes the susceptibility of a reef coral to bleaching. Coral Reefs 21:119-126

Cantin NE, Lough JM (2014) Surviving coral bleaching events: Porites growth anomalies on the Great Barrier Reef. PLoS ONE 9:e88720

Connolly SR, Lopez-Yglesias MA, Anthony KRN (2012) Food availability promotes rapid recovery from thermal stress in a scleractinian coral. Coral Reefs 31:951-960

Dustan P, Halas JC (1987) Changes in the reef-coral community of Carysfort Reef, Key Largo, Florida: 1974 to 1982. Coral Reefs 6:91-106

Edmunds PJ (1994) Evidence that reef-wide patterns of coral bleaching may be the result of the distribution of bleaching susceptible clones. Mar Biol 121:137-142

Fitt WK, McFarland FK, Warner ME, Chilcoat GC (2000) Seasonal patterns of tissue biomass and densities of symbiotic dinoflagellates in reef corals and relation to coral bleaching. Limnol Oceanogr 45:677-685

Fitt WK, Brown BE, Warner ME, Dunne RP (2001) Coral bleaching: interpretation of thermal tolerance limits and thermal thresholds in tropical corals. Coral Reefs 20:51-65

FRRP (2011) Coral Bleaching In-water Rapid Assessment Protocol 2011. Florida Reef Resilience Program, The Nature Conservancy. http://frrp.org/DRMTraininghandouts/FRRPbleachingpro tocol2011.pdf
Gardner TA, Côté IM, Gill JA, Grant A, Watkinson AR (2003) Longterm region-wide declines in Caribbean corals. Science 301:958-960

Gintert B, Gracias N, Gleason ACR, Lirman D, Dick M, Kramer P, Reid P (2009) Second-generation landscape mosaics of coral reefs. In: Proceedings of the 11th international coral reef symposium 1:577-581

Glynn PW (1990) Coral mortality and disturbance to coral reefs in the eastern tropical Pacific. In: Glynn PW (ed) Global ecological consequences of the 1982-83 El Nino-Southern Oscillation. Elsevier, Amsterdam, pp 55-126

Glynn PW (1993) Coral reef bleaching: ecological perspectives. Coral Reefs 12:1-17

Glynn PW, Maté JM, Baker AC, Calderon MO (2001) Coral bleaching and mortality in Panamá and Ecuador during the 1997-98 El Niño-Southern Oscillation event: spatial/temporal patterns and comparisons with the 1982-83 event. Bull Mar Sci 69:79-110

Grottoli AG, Warner ME, Levas SJ, Aschaffenburg MD, Schoepf V, McGinley M, Baumann J, Matsui Y (2014) The cumulative impact of annual coral bleaching can turn some coral species winners into losers. Glob Change Biol 20:3823-3833

Guest JR, Baird AH, Maynard JA, Muttaqin E, Edwards A, Campbell S, Yewdall K, Affendi YA, Chou LM (2012) Contrasting patterns of coral bleaching susceptibility in 2010 suggest an adaptive response to thermal stress. PLoS ONE 7:e33353

Guest JR, Low J, Tun K, Wilson B, Ng C, Raingeard D, Ulstrup KE, Tanzil JTI, Todd PA, Toh TC, McDougald D, Chou LM, Steinberg PD (2016) Coral community response to bleaching on a highly disturbed reef. Sci Rep 6:20717

Hoegh-Guldberg O (1999) Climate change, coral bleaching and the future of the world's coral reefs. Mar Fresh Res 50:839-866

Hoegh-Guldberg O, Mumby PJ, Hooten AJ, Steneck RS, Greenfield P, Gomez E, Harvell CD, Sale PF, Edwards AJ, Caldeira K, Knowlton N, Eakin CM, Iglesias-Prieto R, Muthiga N, Bradbury RH, Dubi A, Hatziolos ME (2007) Coral reefs under rapid climate change and ocean acidification. Science 318:1737-1742

Kuffner IB, Lidz BH, Hudson JH, Anderson JS (2015) A century of ocean warming on Florida Keys coral reefs: historic in situ observations. Estuar Coast 38:1085-1096

LaJeunesse TC, Smith RT, Finney J, Oxenford H (2009) Outbreak and persistence of opportunistic symbiotic dinoflagellates during the 2005 Caribbean mass coral 'bleaching' event. Proc Roy Soc B 276:4139-4148

Levitan DR, Boudreau W, Jara J, Knowlton N (2014) Long-term reduced spawning in Orbicella coral species due to temperature stress. Mar Ecol Prog Ser 515:1-10

Lirman D, Fong P (2007) Is proximity to land-based sources of coral stressors an appropriate measure of risk to coral reefs? An example from the Florida Reef Tract. Mar Pollut Bull 54:779-791

Lirman D, Gracias NR, Gintert BE, Gleason ACR, Reid RP, Negahdaripour S, Kramer P (2007) Development and application of a video-mosaic survey technology to document the status of coral reef communities. Env Monit Assess 125:59-73

Liu G, Strong AE, Skirving W, Arzayus LF (2006) Overview of NOAA coral reef watch program's near-real time satellite global coral bleaching monitoring activities. Proc 10th Int Coral Reef Symp 1:1783-1793

Manzello DP (2015) Rapid recent warming of coral reefs in the Florida Keys. Sci Rep 5:16762

Manzello DP, Berkelmans R, Hendee JC (2007a) Coral bleaching indices and thresholds for the Florida Reef Tract, Bahamas, and St. Croix, US Virgin Islands. Mar Pollut Bull 54:1923-1931 
Manzello DP, Brandt M, Smith TB, Lirman D, Hendee JC, Nemeth R (2007b) Hurricanes benefit bleached corals. Proc Natl Acad Sci USA 104:12035-12039

Manzello DP, Warner ME, Stabenau E, Hendee JC, Lesser MP, Jankulak M (2009) Remote monitoring of chlorophyll fluorescence in two reef corals during the 2005 bleaching event at Lee Stocking Island, Bahamas. Coral Reefs 28:209-214

Manzello DP, Enochs IC, Melo N, Gledhill DK, Johns EM (2012) Ocean acidification refugia of the Florida Reef Tract. PLoS ONE 7:e41715

Manzello DP, Enochs IC, Kolodziej G, Carlton R (2015a) Recent decade of growth and calcification of Orbicella faveolata in the Florida Keys: an inshore-offshore comparison. Mar Ecol Prog Ser 521:81-89

Manzello DP, Enochs IC, Kolodziej G, Carlton R (2015b) Coral growth patterns of Montastraea cavernosa and Porites astreoides in the Florida Keys: the importance of thermal stress and inimical waters. J Exp Mar Biol Ecol 471:198-207

Maynard JA, Anthony KRN, Marshall PA, Masiri I (2008) Major bleaching events can lead to increased thermal tolerance in corals. Mar Biol 155:173-182

McClanahan TR (2017) Changes in coral sensitivity to thermal anomalies. Mar Ecol Prog Ser 570:71-85

McClanahan TR, Muthiga NA (2014) Community change and evidence for variable warm-water temperature adaptation of corals in Northern Male Atoll, Maldives. Mar Pollut Bull 80:107-113

Miller J, Muller E, Rogers C, Waara R, Atkinson A, Whelan KRT, Patterson M, Witcher B (2009) Coral disease following massive bleaching in 2005 causes $60 \%$ decline in coral cover on reefs in the US Virgin Islands. Coral Reefs 28:925-937

Mumby PJ, Chisholm JRM, Edwards AJ, Andrefouet S, Jaubert J (2001) Cloudy weather may have saved Society Island reef corals during the 1998 ENSO event. Mar Ecol Prog Ser 222:209-216

Nakamura R, van Woesik R (2001) Water-flow rates and passive diffusion partially explain differential survival of corals during the 1998 bleaching event. Mar Ecol Prog Ser 212:301-304

Neal BP, Ken A, Treibitz T, Beijboom O, O'Connor G, Coffroth MA, Knowlton N, Kriegman D, Mitchell BG, Kline DI (2016) Caribbean massive corals not recovering from repeated thermal events during 2005-2013. Ecol Evol 7:1339-1353

NOAA Coral Program (2014) National Coral Reef Monitoring Plan. NOAA Coral Reef Conservation Program, Silver Spring, MD, 39 $\mathrm{pp}$

NOAA Coral Reef Watch (2014) Coral Reef Watch-annual summaries of thermal conditions related to coral bleaching for
U.S. National Coral Reef Monitoring Program (NCRMP) jurisdictions. https://coralreefwatch.noaa.gov/satellite/analyses_ guidance/2014_annual_summaries_thermal_stress_conditions_ NCRMP.pdf

NOAA Coral Reef Watch (2015) Annual Summaries of Thermal Conditions Related to Coral Bleaching for NCRMP jurisdictions. https://coralreefwatch.noaa.gov/satellite/analyses_guidance/2015_ annual_summaries_bleaching_thermal_conditions_NCRMP.pdf

Oliver TA, Palumbi SR (2011) Do fluctuating temperature environments elevate coral thermal tolerance? Coral Reefs 30:429-440

Porter JW, Meier OW (1992) Quantification of loss and change in Floridian reef coral populations. Am Zool 32:625-640

Prada C, DeBiasse MB, Neigel JE, Yednock B, Stake JL, Forsman ZH, Baums IB, Hellberg ME (2014) Genetic species delineation among branching Caribbean Porites corals. Coral Reefs 33:1019-1030

Pratchett MS, McCowan D, Maynard JA, Scott F, Heron SF (2013) Changes in bleaching susceptibility among corals subject to ocean warming and recurrent bleaching in Moorea, French Polynesia. PLoS ONE 8:e70443

Precht WF, Gintert BE, Robbart ML, Fura R, van Woesik R (2016) Unprecedented disease-related coral mortality in Southeastern Florida. Sci Rpt 6:31374

Riegl B, Purkis S (2015) Coral population dynamics across consecutive mass mortality events. Glob Change Biol 22:3995-4005

Ruzicka RR, Colella MA, Porter JW, Morrison JM, Kidney JA, Brinkhuis V, Lunz KS, Macaulay KA, Bartlett LA, Meyers MA, Colee J (2013) Temporal changes in benthic assemblages on Florida Keys reefs 11 years after the 1997/1998 El Niño. Mar Ecol Prog Ser 489:125-141

Schoepf V, Grottoli AG, Levas SJ, Aschaffenburg MD, Baumann JH, Matsui Y, Warner ME (2015) Annual coral bleaching and the long-term recovery capacity of coral. Proc Roy Soc B 282:20151887

Siebeck UE, Logan D, Marshall NJ (2009) CoralWatch - a flexible coral bleaching monitoring tool for you and your group. Proc $11^{\text {th }}$ Int Coral Reef Symposium 1:549-553

Team R (2015) RStudio: Integrated development for R. RStudio Inc, Boston, MA

Thompson DM, van Woesik R (2009) Corals escape bleaching in regions that recently and historically experienced frequent thermal stress. Proc Roy Soc B 276:2893-2901

van Woesik R, Houk P, Isechal AL, Idechong JW, Victor S, Golbuu Y (2012) Climate-change refugia in the sheltered bays of Palau: analogs of future reefs. Ecol Evol 2:2474-2484 